\title{
Index of Expandability
}

National Cancer Institute

\section{Source}

National Cancer Institute. Index of Expandability. NCI Thesaurus. Code C67337.

An index reflecting distensibility of elastic organ(s) defined as the change in volume per unit change in pressure $(\mathrm{dV} / \mathrm{dP})$. 